\title{
Our Sense of the Real
}





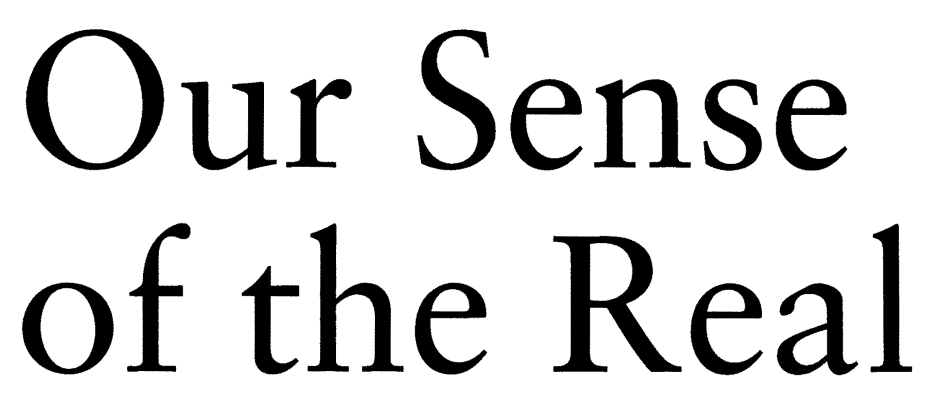

Aesthetic Experience and Arendtian Politics

\section{Kimberley Curtis}


Copyright $\odot 1999$ by Cornell University

All rights reserved. Except for brief quotations in a review, this book, or parts thereof, must not be reproduced in any form without permission in writing from the publisher. For information, address Cornell University Press, Sage House, 5 I 2 East State Street, Ithaca, New York 14850.

First published 1999 by Cornell University Press

Printed in the United States of America

\section{Library of Congress Cataloging-in-Publication Data}

Curtis, Kimberley, 1956-

Our sense of the real : aesthetic experience and Arendtian politics / Kimberley Curtis.

p. $\mathrm{cm}$.

Includes bibliographical references and index.

ISBN o-8014-3577-3. - ISBN o-8014-8640-8 (pbk.)

I. Arendt, Hannah-Contributions in political science. 2. Arendt, Hannah-Aesthetics. 3. Aesthetics-Political aspects. I. Title.

JC25r.A74C87 1999

320.5'092-dc2I

$99-31256$

Cornell University Press strives to use environmentally responsible suppliers and materials to the fullest extent possible in the publishing of its books. Such materials include vegetable-based, low-VOC inks and acid-free papers that are recycled, totally chlorine-free, or partly composed of nonwood fibers. Books that bear the logo of the FSC (Forest Stewardship Council) use paper taken from forests that have been inspected and certified as meeting the highest standards for environmental and social responsibility. For further information, visit our website at www.cornellpress.cornell.edu.

Cloth printing

Paperback printing
I0 987765432 I

I0 $98765432 \mathrm{I}$ 
For Phyllis Mae Curtis

and Hugh Paul Curtis 
To write across the chalkboard, putting up there in public words you have dredged, sieved up from dreams, from behind screen memories, out of silence-words you have dreaded and needed in order to know you exist.

I mean all the times when people have summoned language into the activity of plotting connections between, and making distinctions among, the elements presented to our senses.

Adrienne Rich, What Is Found There

We could scarcely be silent without being tormented by the damning thought that speaking might have saved us.

Thucydides, The Peloponnesian War 